\title{
Malignant non-dysgerminomatous germ cell tumor of ovary
}

INSERM

\section{Source}

INSERM. (1999). Orphanet: an online rare disease and orphan drug data base. Malignant non-dysgerminomatous germ cell tumor of ovary. ORPHA:206538

Malignant non-dysgerminomatous germ cell tumor of ovary is a rare malignant germ cell tumor of ovary (see this term) arising from germ cells in the ovary, frequently unilateral at diagnosis, usually presenting during adolescence with pelvic mass, fever, vaginal bleeding and acute abdomen, with certain subtypes being occasionally associated with isosexual precocity, virilization, hyperthyroidism or carcinoid syndrome (see this term). Histologically they comprise the following: embryonal carcinoma, Yolk sac tumor, polyembryoma and mixed germ cell tumor. 